\title{
Braucht dieser Mann Testosteron?
}

\author{
Erektionsstörungen, Lustlosigkeit, schwindende Muskeln - diese Symptome \\ können Zeichen eines Testosteronmangels sein. Da stellt sich die Frage, ob eine \\ Testosterongabe den Männern das Altern leichter machen kann. Doch was ist \\ normal, und wann liegt ein behandlungsbedürftiges Hormondefizit vor?
}

— Bei Männern gibt es kein Klimakterium. Dennoch klagen einige alternde Männer über Symptome, die u. a. durch einen Androgenmangel entstehen können. Die Bandbreite der Symptome ist groß: von Erektionsstörungen und Libidoverlust über Antriebslosigkeit bis zur Zunahme des Fettgewebes und Abnahme der Knochendichte (Tab. 1). Das Problem: Alle diese Symptome sind unspezifisch und können neben dem Hypogonadismus auch andere Ursachen haben.

Um das Hormondefizit nachzuweisen, ist die Bestimmung des Testosteronspiegels notwendig. Sie ist z. B. bei Erektionsstörungen und bei Männern mit Osteoporose ohnehin Standard, denn diese Erkrankungen sind relativ oft durch einen Hypogonadismus bedingt. Zweckmäßig ist die Messung des Gesamttestosterons im Serum. Wegen der zirkadianen Rhythmik sollte die Blutabnahme zwischen 7 und $11 \mathrm{Uhr}$ morgens erfolgen.

\section{Wann liegt ein Mangel vor?}

Das zweite Problem: Derzeit gibt es keine exakte Definition eines Testosteronmangels. Dass die Hormonproduktion mit dem Alter sinkt, ist normal. Bereits $\mathrm{ab}$ dem fünften Lebensjahrzehnt nimmt die Hormonproduktion der Hoden ab, der Spiegel des freien, biologisch aktiven Testosterons im Blut sinkt im Schnitt um $1 \%$ pro Jahr. Dennoch weisen nicht alle Männer mit niedrigem Testosteronspiegel entsprechende Symptome auf.

Als normal gilt ein Serum-Testosteronspiegel über $12 \mathrm{nmol} / \mathrm{l}(350 \mathrm{ng} / \mathrm{dl})$. Einig sind sich die andrologischen Fachgesellschaften außerdem darüber, dass Patienten mit einem Testosteronspiegel unter $8 \mathrm{nmol} / \mathrm{l}(230 \mathrm{ng} / \mathrm{dl})$ von einer Substitution profitieren [1]. Werte zwi- schen 8 und $12 \mathrm{nmol} / \mathrm{l}$ liegen somit in einer Grauzone. Bestehen bei diesen Patienten Symptome eines Testosteronmangels, wird empfohlen, SerumTestosteron wiederholt zu bestimmen und zusätzlich das sexualhormonbindende Globulin (SHBG) zu messen, um das freie Testosteron zu berechnen.

\section{Schlucken, spritzen oder kleben?}

Die Substitution von Testosteron ist nur dann indiziert, wenn neben dem objektiven Defizit auch körperliche Symptome vorliegen. Die Testosteronsubstitution kann subkutan, intramuskulär, transdermal oder oral erfolgen. Die Auswahl eines entsprechenden Präparats muss individuell erfolgen. Bessern sich die Symptome nach drei bis sechs Monaten nicht, sollte das Testosteron wieder abgesetzt werden, heißt es in den Leitlinien.

\section{Prostatakarzinom ausschließen!} Wichtig ist, vor Beginn einer Testosteronsubstitution ein Prostatakarzinom auszuschließen bzw. das Risiko des Patienten für diesen Tumor abzuschätzen, denn Testosteron stimuliert das Wachs-

\section{Tabelle 1}

\section{Mögliche Symptome eines Testosteronmangels}

- Nachlassende Libido

_ Erektile Dysfunktion

_ Erniedrigte Muskelmasse und -kraft

- Vermehrtes Körperfett

- Verminderte Knochendichte, Osteoporose

_ Verminderte Vitalität

- Depressive Verstimmungen

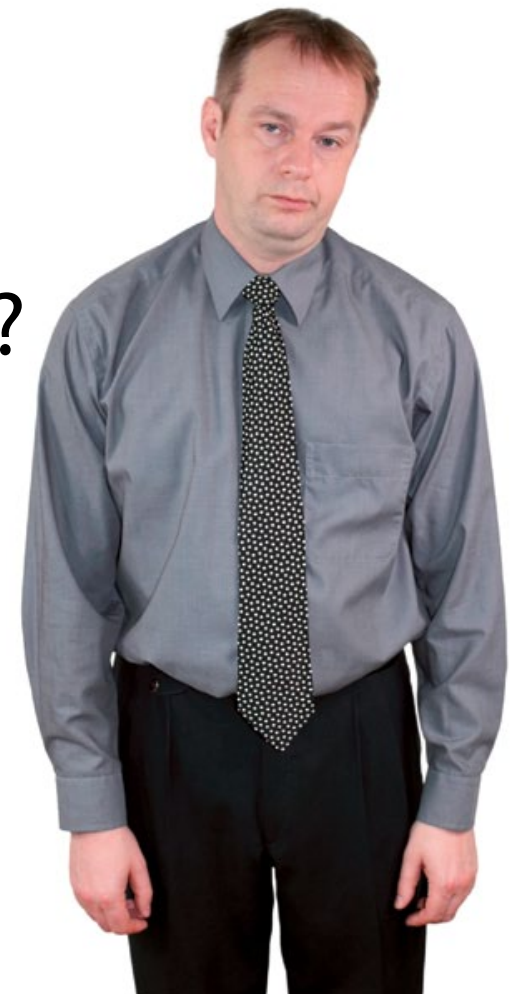

Vielleicht ein Fall für Hormone.

tum eines Prostatakarzinoms. Eine digitale rektale Untersuchung und die Messung des PSA-Werts sind daher unerlässlich. Nach dem Beginn der Testosteronsubstitution sollten regelmäßig Kontrollen der Prostata erfolgen, und zwar nach drei bis sechs Monaten, nach zwölf Monaten und danach einmal jährlich.

\section{Und was bringt die Substitution?}

Positive Effekte einer Testosteronsubstitution sind $\mathrm{u}$. a. bei hypogonadalen Männern nachweisbar, die unter erektiler Dysfunktion und/oder verminderter Libido leiden. Es gibt Hinweise darauf, dass die kombinierte Anwendung von PDE-5-Hemmern und Testosteron bei diesen Patienten synergistisch wirkt.

Auch hypogonadale Männer mit Osteopenie oder Osteoporose profitieren nachweislich von der Substitution, da Testosteron die Knochendichte steigern kann. Außerdem kann Testosteron eine Verminderung der Fettmasse bewirken. Eine Verbesserung von Muskelfunktion und positive metabolische Effekte liegen nahe, sind jedoch nicht ausreichend durch Studien belegt. Zur Auswirkung auf das kardiovaskuläre Risiko gibt es widersprüchliche Ergebnisse.

DR. JUDITH NEUMAIER •

\footnotetext{
- Quellen:

1. Wang $C$ et al. J Reproduktionsmed Endo-

krinol 2010;7:60-66
}

2. Popken G. UroNews 2012;3:36-38 